\title{
Effects of Seasonal Temperature Variation on Slurry Temperature and Biogas Composition of a Commercial Fixed-Dome Anaerobic Digester Used in Bangladesh
}

\author{
A. S. M. Younus Bhuiyan Sabbir ${ }^{1,2}$, Chayan Kumer Saha ${ }^{1, *}{ }^{\mathbb{D}}$, Rajesh Nandi ${ }^{1}{ }^{\mathbb{C}}$, Md. Forid Uz Zaman ${ }^{1}$, \\ Md. Monjurul Alam ${ }^{1}$ and Shiplu Sarker ${ }^{3}$ (D) \\ 1 Department of Farm Power and Machinery, Bangladesh Agricultural University, \\ Mymensingh 2202, Bangladesh; ybsabbir@kau.edu.bd (A.S.M.Y.B.S.); rajesh@bau.edu.bd (R.N.); \\ fuzshuvo10@gmail.com (M.F.U.Z.); mmalam.bau@gmail.com (M.M.A.) \\ 2 Department of Farm Power and Machinery, Khulna Agricultural University, Khulna 9202, Bangladesh \\ 3 Department of Manufacturing and Civil Engineering, \\ Norwegian University of Science and Technology (NTNU), 2815 Gjøvik, Norway; shiplu.sarker@ntnu.no \\ * Correspondence: cksaha@bau.edu.bd; Tel.: +880-1715626517
}

Citation: Sabbir, A.S.M.Y.B.; Saha, C.K.; Nandi, R.; Zaman, M.F.U.; Alam, M.M.; Sarker, S. Effects of Seasonal Temperature Variation on Slurry Temperature and Biogas Composition of a Commercial Fixed-Dome Anaerobic Digester Used in Bangladesh. Sustainability 2021, 13, 11096. https://doi.org/10.3390/ su131911096

Academic Editors: Antoni Sánchez and Anna Grosser

Received: 23 July 2021

Accepted: 2 October 2021

Published: 8 October 2021

Publisher's Note: MDPI stays neutral with regard to jurisdictional claims in published maps and institutional affiliations.

Copyright: (c) 2021 by the authors. Licensee MDPI, Basel, Switzerland. This article is an open access article distributed under the terms and conditions of the Creative Commons Attribution (CC BY) license (https:/ / creativecommons.org/licenses/by/ $4.0 /)$.
Abstract: Biogas is produced in Bangladesh mostly through fixed-dome anaerobic digesters, which usually operate without any temperature controller. An experiment was conducted to monitor the seasonal temperature variation inside a fixed-dome type digester and its effect on biogas composition. A commercial-scale digester with a working volume of $350 \mathrm{~m}^{3}$ was used for this study. Three k-type thermocouple sensors were used to monitor the ambient, biogas, and slurry temperatures in real-time. The results showed that the average ambient temperature in the autumn, late autumn, and winter was $29.05,22.90$, and $17.64{ }^{\circ} \mathrm{C}$, respectively. The average slurry temperature in the autumn $\left(30.38^{\circ} \mathrm{C}\right)$ was higher than in the late autumn $\left(29.36^{\circ} \mathrm{C}\right)$ and in the winter $\left(25.76^{\circ} \mathrm{C}\right)$. The highest and lowest slurry temperatures were found to be 31.11 and $24.47^{\circ} \mathrm{C}$, respectively, which indicated that the digester worked within a wide temperature range, establishing both psychrophilic and mesophilic operational conditions. Higher methane concentrations were observed in the autumn than in the late autumn and winter. The $\mathrm{CO}_{2}$ and $\mathrm{H}_{2} \mathrm{~S}$ concentrations were higher in the winter than those of in the autumn and late autumn. The electricity generation in the winter was $47.85 \%$ and $45.15 \%$ lower than in the autumn and late autumn, respectively.

Keywords: anaerobic digestion; fixed-dome digester; temperature; seasonal variation; biogas

\section{Introduction}

Bangladesh is a densely populated country with a population of around 170 million [1]. Per capita electricity consumption in the country is $375 \mathrm{kWh}$ per year [2], which is the lowest among the South Asian countries, with corresponding consumption in India of $970 \mathrm{kWh}$, Sri Lanka of $650 \mathrm{kWh}$, and Pakistan of $590 \mathrm{kWh}$, respectively [3]. The energy generation in Bangladesh mostly depends on fossil fuels (where natural gas is the main source) with a mere share of $1.61 \%$ from renewable sources [4]. As of today, the country has a limited natural gas reserve (i.e., 12 trillion cubic feet till to date) which may run only for the next 10-12 years [5]. Due to rapid industrialization and continuous population growth, the countrywide demand for energy is rising swiftly, causing a tremendous pressure on the present natural gas demand. As a result, there has been an ongoing search for suitable alternative energy sources for power generation with a potential for greenhouse gas mitigation. Biogas seems to be a promising alternative in this context, as it is produced from renewable sources, often from organic waste materials, which has low or no impact towards greenhouse gas emissions, once utilized for energy production.

Biogas is produced through anaerobic digestion (AD) by the action of microorganisms in an anoxic environment. There are several factors which influence the performance of 
AD. Digester temperature is one of the vital factors which influences microbial activity and growth. The AD typically takes place in three distinct temperature regions: psychrophilic $\left(<30{ }^{\circ} \mathrm{C}\right)$, mesophilic $\left(30-40{ }^{\circ} \mathrm{C}\right)$, and thermophilic $\left(50-60{ }^{\circ} \mathrm{C}\right)$ [6]. The methanogens are mainly effective in mesophilic and thermophilic regions where $\mathrm{AD}$ shows higher productivity. Previous studies on the effect of temperature on anaerobic digestion found higher methane yield in the mesophilic temperature range as compared to thermophilic condition $[7,8]$. Generally, a temperature range of $35-37^{\circ} \mathrm{C}$ is suggested optimum for methane production in mesophilic conditions [9]. However, at a lower temperature range, such as at $22-28{ }^{\circ} \mathrm{C}$, methane production tends to be $23-30 \%$ lower than that at $35^{\circ} \mathrm{C}[6,10]$. Schmidt et al. [11] found that fluctuations in temperature reduce the biogas productivity of AD. Barik and Murugan [12] observed that methanogens are very sensitive to speedy changes in temperature with any drastic change resulting in process failure, which is thus recommended to be avoided by implementing correct measures. The correlation between the reaction rate and the biological process with temperature can be shown by Equation (1) [7]:

$$
r_{T}=r_{20} \theta^{(T-20)}
$$

where $r_{T}$ represents the reaction rate constant at temperature $\mathrm{T}, r_{20}$ denotes the reaction rate constant at $20^{\circ} \mathrm{C}, \theta$ represents the temperature activity constant, and $T$ is the temperature.

Poultry is one of the major livestock sectors in Bangladesh [13]. The poultry population of the country is around 312 million, which produces around 2.1 MTPY (million tons per year) of waste (dry matter) with a corresponding production of 12.3 MTPY from cattle, 0.7 MTPY from buffalo, 1.5 MTPY from goats, and 0.2 MTPY from sheep, respectively [14]. There are around 20,000 farms having 1000 or more birds, which have a considerable potential to generate electricity using the produced waste [15]. Talukder [15] showed that the poultry litter had an electricity generation potential of $490 \mathrm{GWh}$ out of the total electricity generation of about $26,604 \mathrm{GWh}$ in the year 2009. In recent development, the poultry population is increasing at a much higher rate than other livestock due to the increased consumption of poultry meat. As the poultry industry grows continuously, it contributes to generate a significant portion of the waste generated from the entire livestock sector. Thus, a systematic waste management strategy to utilize this waste in an environmentally friendly way is urgently needed.

In Bangladesh, there are around 91,350 domestic and commercial biogas plants in operation [16]. Most of the plants are single substrate (cattle or poultry manure)-based and use a fixed-dome type digester. These plants are operating without any heating system for temperature control, and their performance among other things depends heavily on ambient temperature [17]. Bangladesh has a sub-tropical monsoon climate containing four major seasons: winter, spring, summer, and autumn [18]. It has a wide seasonal variation in rainfall, with moderately warm temperatures and high humidity [19]. The average temperature from April to August is about $30^{\circ} \mathrm{C}$ [20], which is around optimum for biogas production [21]. However, the temperature starts to fall from September till February (winter) [20]. In the winter, the mean temperature is around $18{ }^{\circ} \mathrm{C}$, which sometimes drops below $10{ }^{\circ} \mathrm{C}$ due to cold waves [19]. The low temperatures in the winter season may influence the performance of $\mathrm{AD}$. Thus far, most of the previous studies $[7,8]$ on the effect of temperature on $\mathrm{AD}$ performance were conducted at a laboratory scale, with studies on commercial-scale digesters being extremely rare. In addition, little information is available on how changes in ambient temperature influence the process temperature of a full-scale anaerobic digester. Kalia et al. [22] evaluated the performance of a fixed-dome digester in India under seasonal temperature variations. They found that a fall in the mean ambient temperature from ca. $26^{\circ} \mathrm{C}$ in the summer to ca. $9^{\circ} \mathrm{C}$ in the winter months resulted in a drop in the digester temperature from ca. 22 to $13^{\circ} \mathrm{C}$. Ihara et al. [23] observed improvement in biogas production with an increase in ambient temperature in a field-scale digester in Japan. Castano et al. [24] evaluated the performance of a small-scale fixed-dome digester in a temperate U.S. climate for 363 days. They observed that the digester temperature below $20{ }^{\circ} \mathrm{C}$ produced less biogas than expected. Besides these studies, the knowledge of 
seasonal temperature effect on commercial-scale digesters in Bangladesh context to date is insufficient. Moreover, studies devoted to poultry manure as a feedstock are even scarcer, with very few previous studies $[22,24]$ reporting the performance of digesters treating cattle manure only. To address this research gap, the aim of the current work was to investigate the effect of seasonal temperature variations on the digester temperature and biogas quality by using a fixed-dome biogas digester treating local poultry litter in Bangladesh conditions.

\section{Materials and Methods}

\subsection{Experimental Site and Biogas Plant}

The experiment was conducted in a poultry farm situated in Gazipur, Bangladesh (GPS coordinates $24^{\circ} 9^{\prime} 41.32^{\prime \prime} \mathrm{N}, 90^{\circ} 25^{\prime} 10.74^{\prime \prime} \mathrm{E}$ ) (Figure 1). An overview of the farm is presented in Table 1 . The farm has 60,000 birds, which produce ca. 12,000 kg of poultry litter per day. The farm is covered by a poultry shed, which is a standard accommodation environment for birds with proper aeration, shelter, safety, and drainage systems. In order to treat the poultry litter for biogas production for electricity generation, the farm uses a fixed-dome type digester of $350 \mathrm{~m}^{3}$, which is made of bricks and constructed underground. The generated poultry litter within the farm is collected using a belt conveyor. After collection, the poultry litter is flushed with water at room temperature to enable feeding into the digester through the inlet. The room temperature and humidity are maintained by a pad and fan cooling system in the summer and by lighting and closing curtains in the winter, respectively. Residue of the digestion, called digestate, is brought out from the digester through the outlet to prevent the increase in biogas exit pressure.

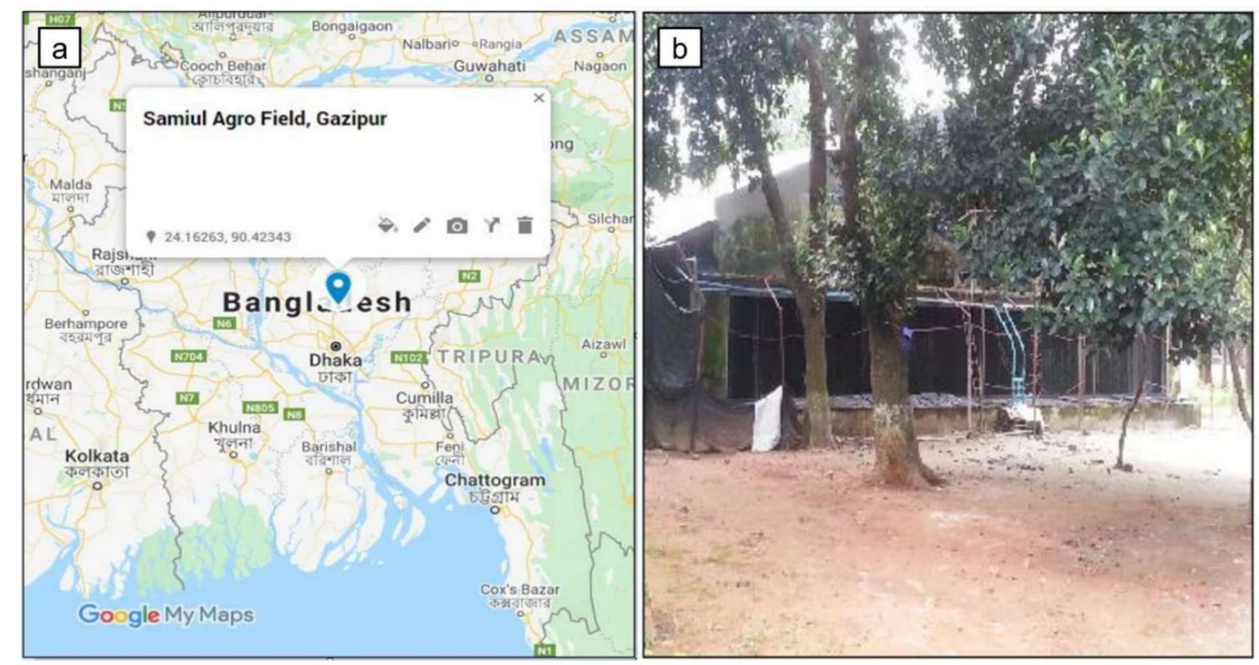

Figure 1. (a) Location of the study site; (b) picture of the farm.

Table 1. An overview of the farm.

\begin{tabular}{ll}
\hline Parameter & Value \\
\hline Capacity of the digester $\left(\mathrm{m}^{3}\right)$ & 350 \\
Digester type & Fixed dome \\
Feedstock & Poultry droppings \\
Population (no. of birds) & 60,000 \\
Waste produced $(\mathrm{kg} / \mathrm{d})$ & 12,000 \\
Waste fed into the digester $(\mathrm{kg} / \mathrm{d})$ & 3000 \\
\hline
\end{tabular}

\subsection{Experiment Period}

Considering the seasonal temperature variation of Bangladesh as stated in the introduction, the experiment was conducted in the autumn, late autumn, and winter seasons, starting from 24 August 2017 till 10 February 2018. Autumn spans from mid-August 
to mid-October, late autumn is from mid-October to mid-December, and winter is from mid-December to mid-February.

\subsection{Experimental Set-Up and Procedure}

For the experiment, a set-up was prepared in a control room where a computer (15BA009DX, HP, USA) and a data logger (CR6, Campbell Scientific Inc., Logan, UT, USA) were placed (Figure 2). The room was facilitated with continuous electricity supply to ensure continuous operation of the computer and the data logger. Temperature at different locations was recorded by the data logger through three different k-type thermocouples (Temperature 107 probe, Campbell Scientific Inc., Logan, UT, USA). Two thermocouples were placed inside the digester at the gas outlet for measuring the biogas temperature and slurry temperature at a depth of $0.91 \mathrm{~m}$ and $2.13 \mathrm{~m}$, respectively, and the other sensor was exposed into the atmosphere for the measurement of ambient temperature (Figure 2). The data logger saved data every minute of the interval, which eventually allowed to process data for every hour and every three hours for display. It was assumed that no temperature gradient exists inside the digester at any depth. Therefore, the single point measurement of the slurry temperature represents the temperature of all points. This assumption is supported by Terradas-III et al. [25], who observed no significant change in slurry temperature with the depth of the digester, namely, $24.80^{\circ} \mathrm{C}$ at $1 \mathrm{~m}, 24.50{ }^{\circ} \mathrm{C}$ at $1.4 \mathrm{~m}$, and $24.40^{\circ} \mathrm{C}$ at $1.8 \mathrm{~m}$ depth, respectively.

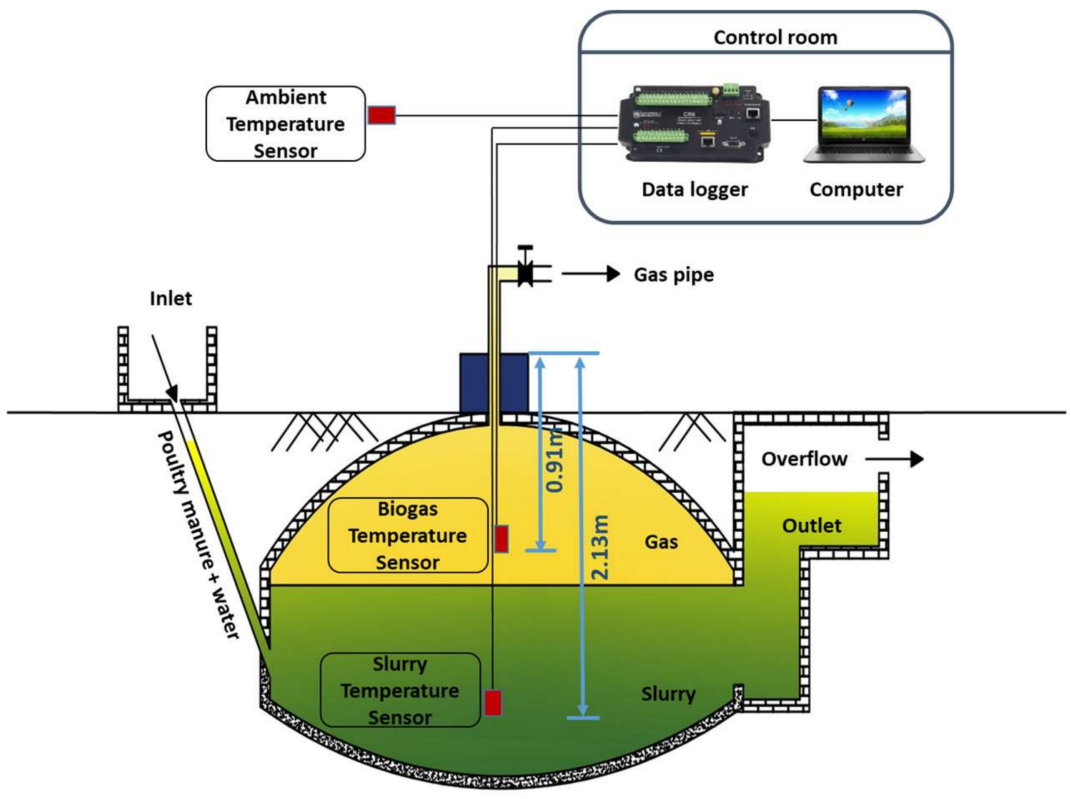

Figure 2. Fixed-dome digester with experimental set-up.

\subsection{Measurement of Different Parameters}

During the experiment, the feedstock and slurry samples were collected for laboratory analysis. The collected samples were brought to the Green Energy Knowledge Hub (GEKH) laboratory at Bangladesh Agricultural University (BAU) for physical and chemical analyses. The total solids (TS) and volatile solids (VS) were determined using the following standard [26], as described by Nasrin et al. [27]. For drying and combustion of samples for TS and VS evaluation, a heating oven (UN30, Memmert, Schwabach, Germany) and a muffle furnace (LE 14/11/ B 150, Nabertherm, Lilienthal, Germany) were used. The pH of the samples was measured by a calibrated $\mathrm{pH} /$ Conductometer $(914 \mathrm{pH} /$ Conductometer, Metrohm, Herisau, Switzerland). The biogas composition $\left(\mathrm{CH}_{4}, \mathrm{CO}_{2}\right.$, and $\left.\mathrm{H}_{2} \mathrm{~S}\right)$ was measured at an interval of around 20 days using a biogas analyzer (Biogas 5000, Geotech Ltd., Coventry, UK). Biogas volume could not be measured due to the unavailability of a 
biogas volume measuring system for the field-scale fixed-dome digester. Instead, the data on daily electricity production ( $\mathrm{kWh} /$ day) from biogas was obtained from the farm owner.

\subsection{Statistical Analysis}

Statistical analysis was performed upon data collection. Significant statistical difference was determined using IBM SPSS Statistics 20 software. Multiple comparison tests were conducted using Tukey's HSD (honestly significant difference) test method.

\section{Results and Discussion}

\subsection{Substrate and Slurry Characteristics}

The substrate and slurry characteristics are presented in Table 2. The TS and VS contents of the substrate were in the range of $6 \%$ to $17 \%$ and $4 \%$ to $11 \%$, respectively. The dry matter content of the input feedstock was found to vary from time to time due to the non-uniform mixing of the poultry litter and water, as the plant owner did not have enough resources for monitoring and controlling the feedstock input at the point of feeding.

Table 2. Substrate and slurry characteristics.

\begin{tabular}{ccccccc}
\hline \multirow{2}{*}{ Date } & \multicolumn{3}{c}{ Substrate } & \multicolumn{3}{c}{ Slurry } \\
\cline { 2 - 7 } & TS (\%) & VS (\%) & pH & TS (\%) & VS (\%) & pH \\
\hline $24-08-17$ & 17.08 & 10.78 & 5.95 & 1.02 & 0.44 & 7.09 \\
$14-09-17$ & 6.45 & 4.26 & 6.27 & 0.83 & 0.33 & 7.63 \\
$09-10-17$ & 10.54 & 6.65 & 7.65 & 1.29 & 0.52 & 8.04 \\
$01-11-17$ & 6.25 & 4.18 & 7.46 & 1.25 & 0.51 & 7.95 \\
$14-12-17$ & 6.5 & 4.12 & 6.39 & 1.15 & 0.46 & 6.96 \\
$04-01-18$ & 10.16 & 6.63 & 6.54 & 1.13 & 0.47 & 6.83 \\
$10-02-18$ & 10.27 & 6.88 & 6.82 & 3.03 & 1.24 & 5.96 \\
\hline
\end{tabular}

The $\mathrm{pH}$ is known to influence enzymatic activity associated with different AD processing steps. Each enzyme is active within only a specific and narrow $\mathrm{pH}$ range and presents its maximum activity at an optimum $\mathrm{pH}$. The $\mathrm{pH}$ value and the stability of the $\mathrm{pH}$ in an anaerobic digester are extremely important to maintain a high rate of methanogenesis, which develops when $\mathrm{pH}$ is kept within a neutral range [28]. The $\mathrm{AD}$ is stabilized at a $\mathrm{pH}$ of 6.5 to 8.2 [29]. In this study, the $\mathrm{pH}$ value of the digester slurry was higher in the autumn than in the late autumn and winter (Table 2). Similar results were obtained by the previous studies $[7,8]$, which observed low $\mathrm{pH}$ levels at low slurry temperatures.

As for TS and VS contents of the digestate, the amounts as compared to those of the input substrate were found to be much less (Table 2) This represents that a significant portion of the VS in the input substrate was involved in the biochemical conversion and therefore turned into biogas.

\subsection{Seasonal and Diurnal Temperature Variation}

The seasonal variation of the ambient temperature and the corresponding slurry and biogas temperature are shown in Figure 3. From the figure, it is evident that the average biogas and slurry temperature decreased with the decrease in average ambient temperature. During the experiment, the maximum ambient temperature was found to be $41.31^{\circ} \mathrm{C}$ on September 23 and the minimum ambient temperature of $5.08^{\circ} \mathrm{C}$ on January 8. Correspondingly, the maximum and minimum biogas temperatures were 32.63 and $16.83{ }^{\circ} \mathrm{C}$ recorded on August 25 and December 4, respectively, while the maximum and minimum recorded slurry temperatures were 31.11 and $24.47^{\circ} \mathrm{C}$ on September 19 and January 16, respectively. The variable slurry temperature throughout the different seasons suggests that the digester established both psychrophilic and mesophilic conditions during its operation. 


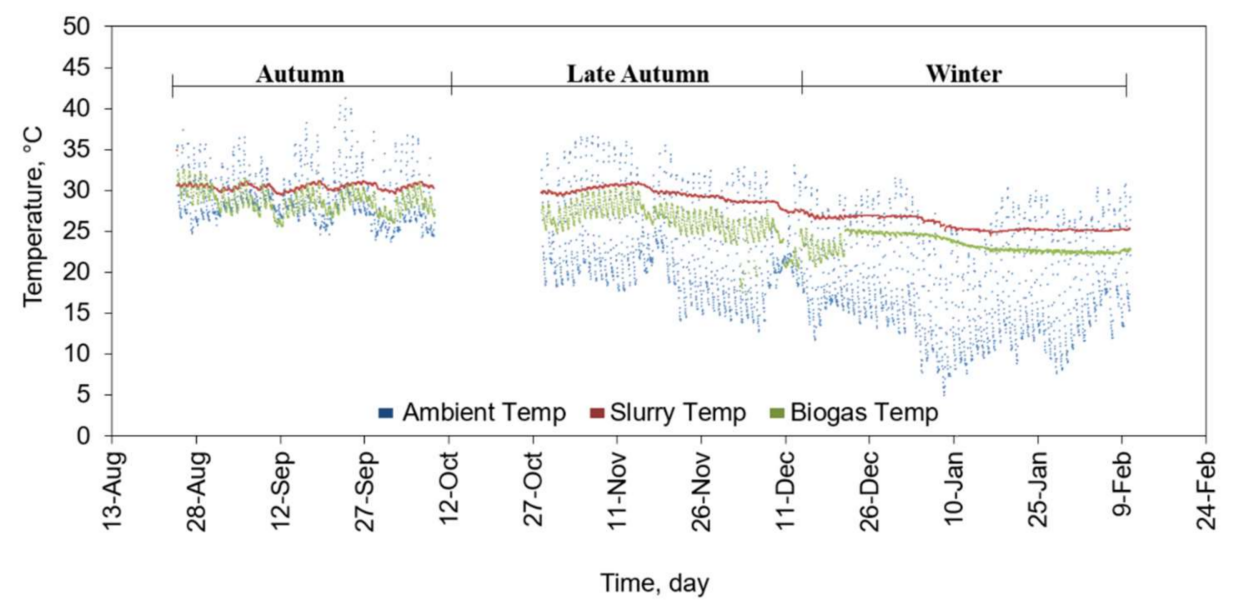

Figure 3. Variation of ambient, biogas, and slurry temperature over the experimental period.

The average ambient temperature in the autumn, late autumn, and winter was $29.05 \pm 3.07^{\circ} \mathrm{C}, 22.90 \pm 5.47{ }^{\circ} \mathrm{C}$, and $17.64 \pm 6{ }^{\circ} \mathrm{C}$, respectively. Due to technical difficulty of the data logger, data from October 10 to October 27 could not be registered. The ambient temperature in the autumn was $6.15^{\circ} \mathrm{C}$ higher than that in the late autumn and $11.41^{\circ} \mathrm{C}$ higher than that in the winter. The results of an ANOVA test showed that the ambient temperature in the autumn was significantly higher than that in the late autumn and winter $(p<0.05)$, respectively (Table 3$)$.

Table 3. Changes in the ambient temperature and slurry temperature.

\begin{tabular}{lcc}
\hline Name of the Season & $\begin{array}{c}\text { Ambient Temperature }\left({ }^{\circ} \mathbf{C}\right) \\
\text { (Mean } \pm \text { SD) }\end{array}$ & $\begin{array}{c}\text { Slurry Temperature }\left({ }^{\circ} \mathbf{C}\right) \\
\text { (Mean } \pm \text { SD) }\end{array}$ \\
\hline Autumn & $29.05 \pm 3.07^{\mathrm{a}}$ & $30.38 \pm 0.38^{\mathrm{a}}$ \\
Late autumn & $22.90 \pm 5.47^{\mathrm{b}}$ & $29.36 \pm 0.96^{\mathrm{a}}$ \\
Winter & $17.64 \pm 6^{\mathrm{c}}$ & $25.76 \pm 0.78^{\mathrm{b}}$ \\
\hline $\mathrm{a}-\mathrm{c}$ Within each column, different letters indicate a significantly increased difference $(p<0.05)$.
\end{tabular}

$\overline{\mathrm{a}-\mathrm{c}}$ Within each column, different letters indicate a significantly increased difference $(p<0.05)$.

The immediate change in the slurry temperature after feeding the digester was monitored and shown in Figure 4. The digester was fed with influent (mixture of poultry litter and water) once daily between $11.00 \mathrm{AM}$ and 12.00 PM throughout the experiment. As shown, the slurry temperature remains unaffected by the addition of the influent.

In the autumn, the maximum ambient and biogas temperature fluctuations were found to be $4.01{ }^{\circ} \mathrm{C}(1: 00 \mathrm{PM})$ and $1.29^{\circ} \mathrm{C}(7: 00 \mathrm{PM})$, respectively (Figure 5$)$. The fluctuation in slurry temperature was very low during the autumn, which is desirable for a stable $\mathrm{AD}$ operation. The average slurry temperature during the autumn was found to be $30.38 \pm 0.38^{\circ} \mathrm{C}$. The variation of the ambient temperature between day and night was around $2.94 \pm 1.41^{\circ} \mathrm{C}$.

In the late autumn, the recorded maximum ambient and biogas temperature fluctuations were $3.44{ }^{\circ} \mathrm{C}(1: 00 \mathrm{PM})$ and $1.19{ }^{\circ} \mathrm{C}(7: 00 \mathrm{PM})$, respectively (Figure 6). The fluctuation in slurry temperature was not significant. The average slurry temperature in the late autumn was $29.36 \pm 0.96{ }^{\circ} \mathrm{C}$, which was $1.02^{\circ} \mathrm{C}$ lower than autumn's slurry temperature. During the night, the ambient temperature dropped by $7.54 \pm 2.14^{\circ} \mathrm{C}$, which although is significant, did not affect the slurry temperature. 

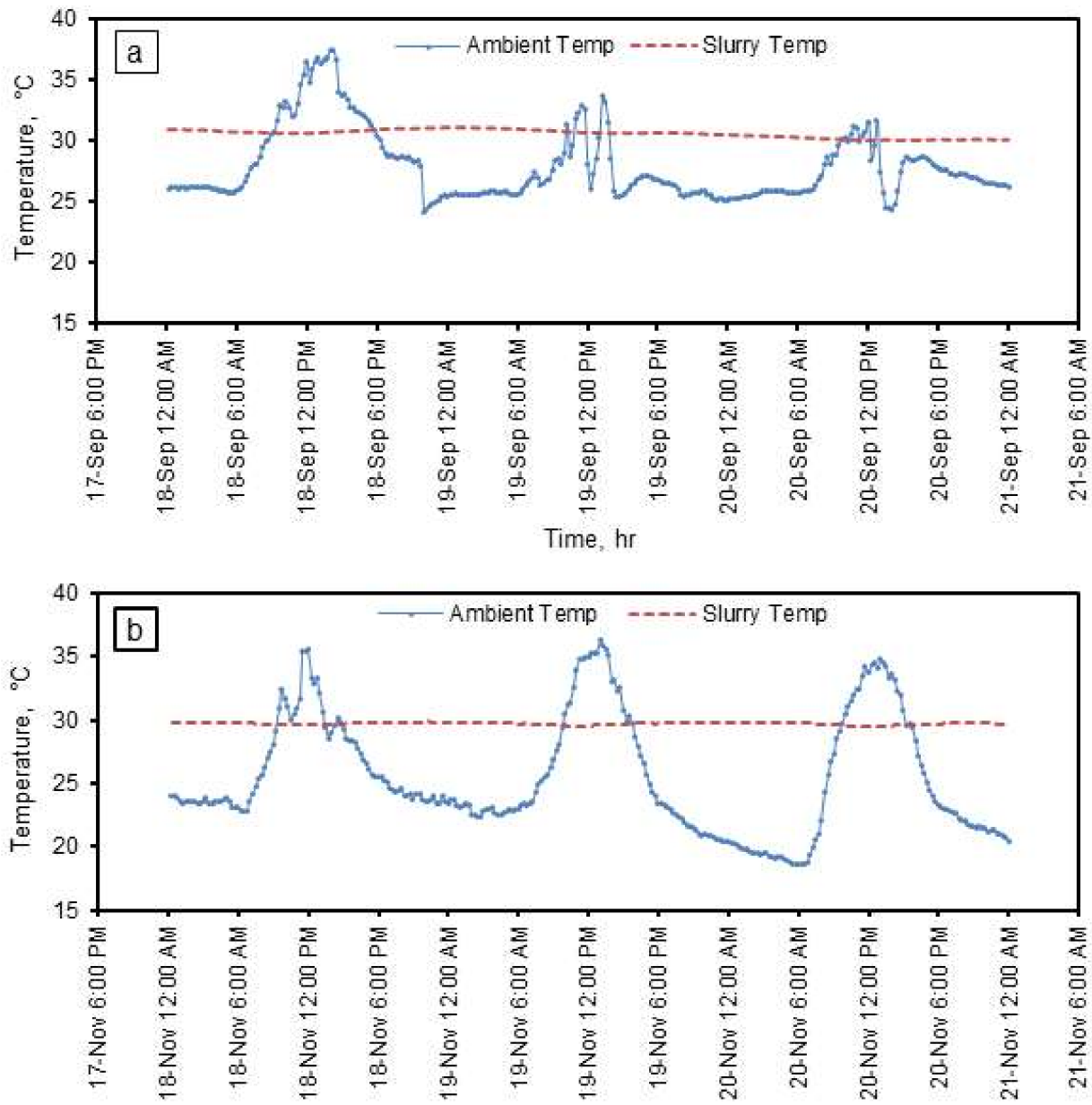

Time, hr

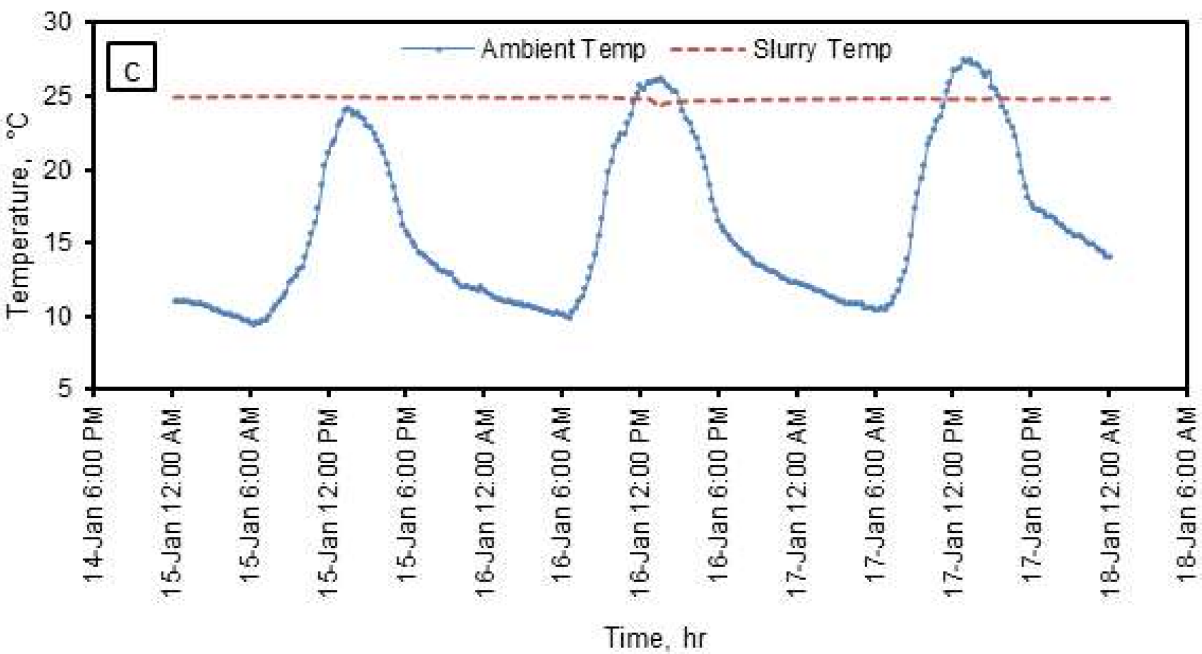

Figure 4. Changes in slurry temperature after feeding in (a) autumn (18 to 21 September 2017), (b) late autumn (18 to 21 November 2017), and (c) winter (15 to 18 January 2018). 

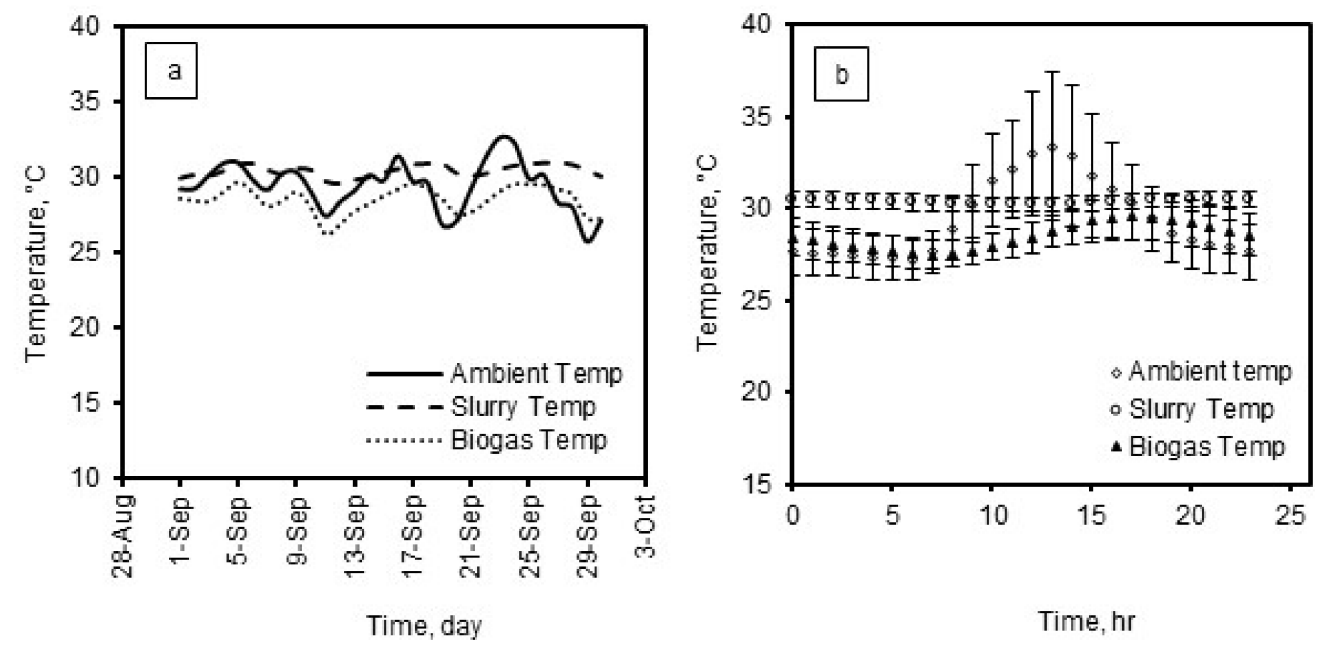

Figure 5. (a) Daily and (b) diel ambient, biogas, and slurry temperature variations in the autumn season.
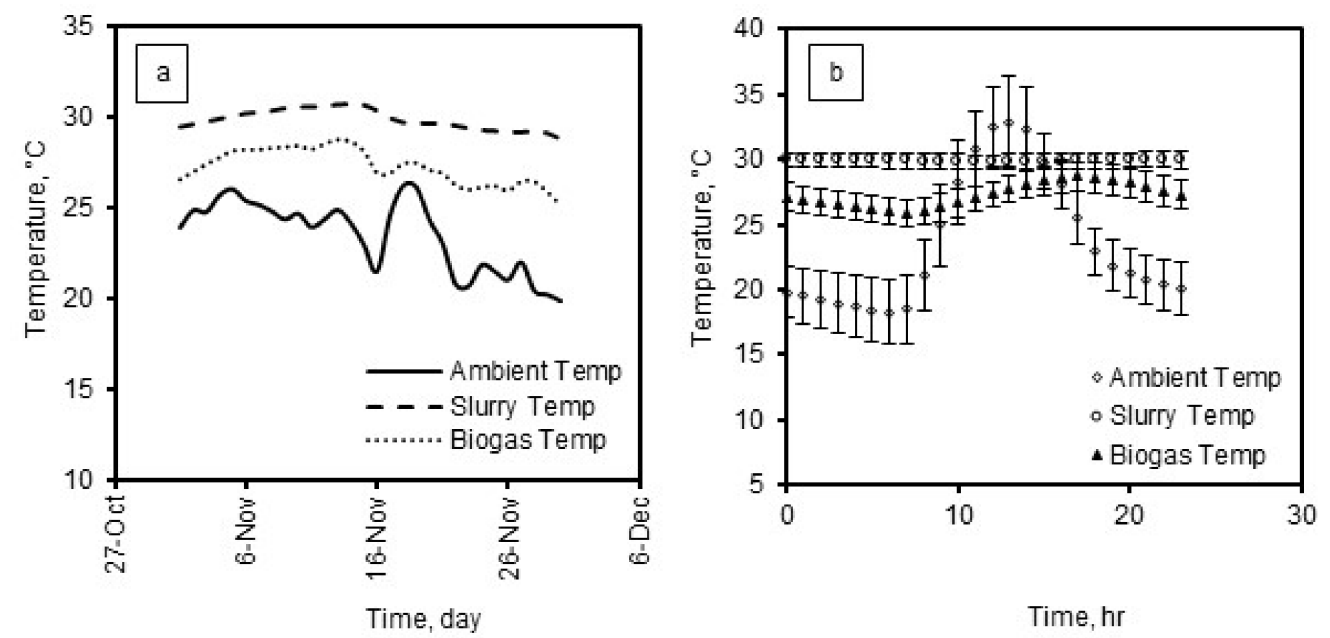

Figure 6. (a) Daily and (b) diel ambient, biogas, and slurry temperature variations in the late autumn season.

The maximum ambient temperature fluctuation in the winter was found to be $4.94{ }^{\circ} \mathrm{C}$ (11:00 AM). The average ambient temperature at $11: 00 \mathrm{AM}$ was $21.63{ }^{\circ} \mathrm{C}$. No significant fluctuation in the slurry temperature was observed in the winter months (Figure 7), but the average slurry temperature in the winter dropped to $25.76 \pm 0.78^{\circ} \mathrm{C}$, which was 5.64 and $4.62{ }^{\circ} \mathrm{C}$ lower than that in the autumn and late autumn, respectively. The ambient temperature at night fell by $8.69 \pm 2.12^{\circ} \mathrm{C}$. This drop in temperature during the night was higher than the above two seasons.

The results of this study showed that during a specific season, the variation of slurry temperature was not related to the variation in ambient temperature, which coincides with the findings of the previous study by Kalia et al. [30]. However, in the long run, the average slurry temperature decreased gradually from the autumn to winter. There was no significant difference in slurry temperature between the autumn and late autumn, but the temperature was significantly lower in the winter $(p<0.05)$. The slurry temperature dropped as the average ambient temperature fell gradually from the late autumn to winter. Similarly, the average biogas temperature also decreased with the drop in average ambient temperature in these periods of the year. Thus, it can be said that the ambient temperature is directly proportional to the biogas and slurry temperature; hence, it may influence the AD performance. 

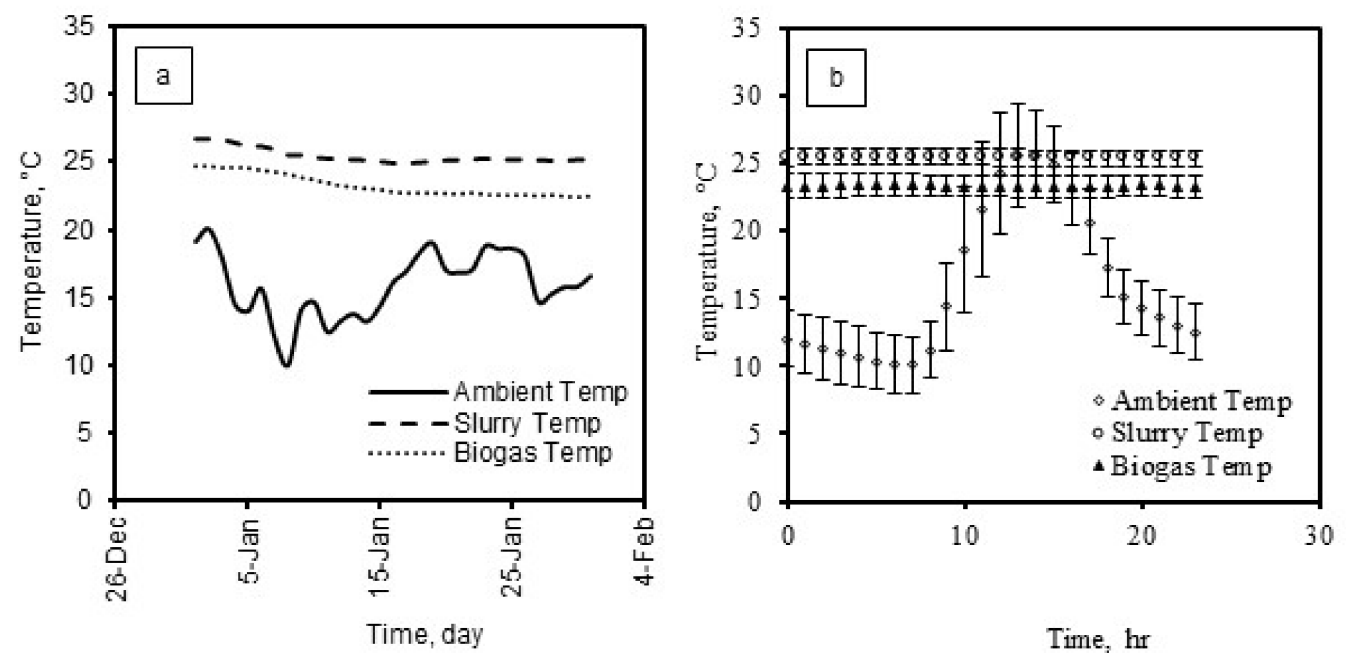

Figure 7. (a) Daily and (b) diel ambient, biogas, and slurry temperature variations in the winter season.

\subsection{Effect on Degradation Efficiency}

Total solids reduction (TSR) and volatile solids reduction (VSR) are two important measures of AD degradation efficiency. In this study, the TSR in the autumn, late autumn, and winter was found to be $89.64 \%, 81.15 \%$, and $79.68 \%$, respectively, and the VSR was $93.45 \%, 88.31 \%$, and $87.44 \%$, respectively (Figure 8 ). It is evident from the results that the degradation efficiency decreased from the autumn to winter as the digester temperature declined from 30.38 to $25.76^{\circ} \mathrm{C}$. During AD, microorganisms break down waste materials into sugars and fatty acids. Fatty acids are then converted into biogas by the action of methane forming bacteria and archaea. This process causes a reduction of solid particles in the organic materials. At low temperature, the metabolic activity of microorganisms decreases, resulting in lower degradation efficiency [31]. Nandi et al. [7] observed low degradation efficiency at lower temperatures than that of higher temperatures. The study obtained the volatile solids degradation of $29-33 \%$ between 35 and $40{ }^{\circ} \mathrm{C}$, and of $12-19 \%$ between 20 and $25^{\circ} \mathrm{C}$. A digester temperature higher than $40{ }^{\circ} \mathrm{C}$ resulted in lower degradation efficiency. The study concluded that an optimum temperature should be maintained to achieve a higher degradation of organic matter.

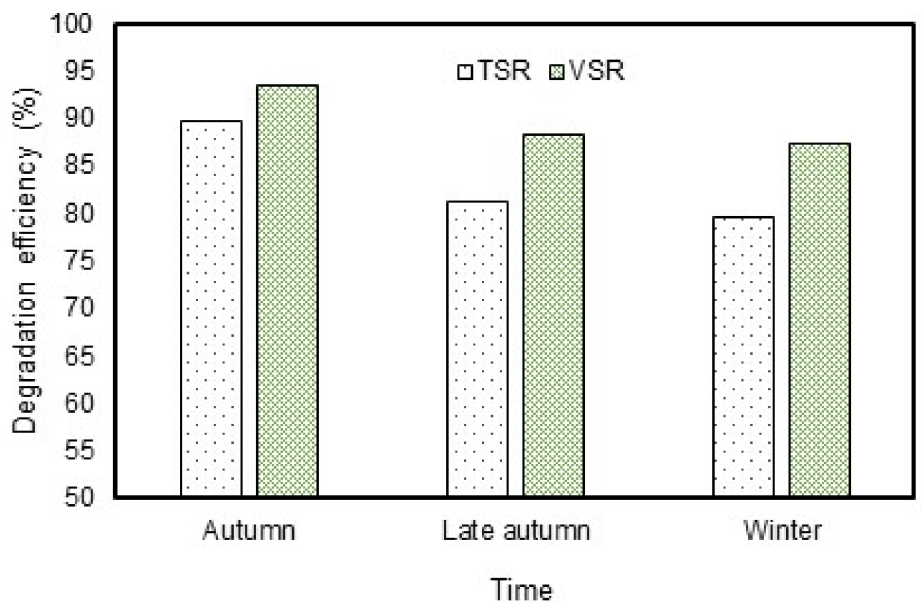

Figure 8. Variation of degradation efficiency.

\subsection{Seasonal Variation of Gas Composition}

According to a number of researchers [32,33], the variations in $\mathrm{CH}_{4}$ production and emissions from biogas plants have been correlated to the slurry temperature. In this study, the slurry temperature in the autumn was higher than that in the winter. The 
seasonal variation of gas composition is shown in Figure 9. It is evident that the methane concentration decreased with the decrease in average temperature from autumn to winter (Figure 9a). The average methane concentration was $61.43 \%, 59.75 \%$, and $56.3 \%$ in the autumn, late autumn, and winter, respectively. Thus, the methane concentration in winter was $8.35 \%$ and $5.77 \%$ less than the methane concentration in the autumn and late autumn, respectively. This observation suggests that the methane production decreases with the decrease in temperature. Similar results were obtained in the study by Vanegas and Bartlett [34], who found lower methane concentration at $20^{\circ} \mathrm{C}(45 \%)$ than at $35^{\circ} \mathrm{C}(62 \%)$. An increase in temperature leads to increased bacterial activity with higher growth rates, faster metabolism, and elevated nutrient demand. If the temperature falls below the optimum range, bacterial metabolism decreases. As a result, methane concentration in biogas decreases or completely disappears with the proportional increase of $\mathrm{CO}_{2}$ level [7]. However, results of the ANOVA test showed that the difference in methane concentration in different seasons was not significant $(p=0.10)$.
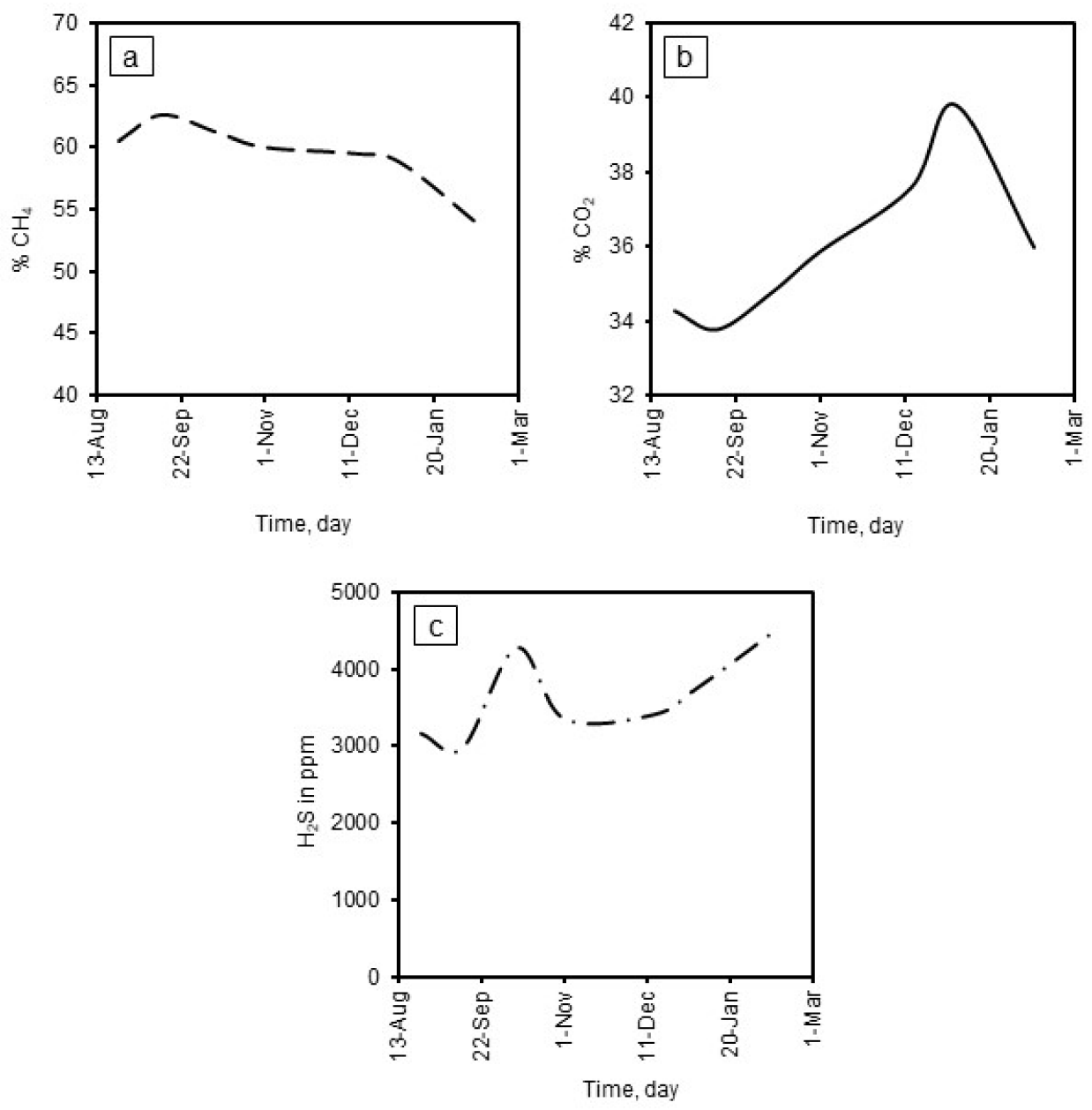

Figure 9. Seasonal variation of biogas composition: (a) $\mathrm{CH}_{4}$; (b) $\mathrm{CO}_{2}$; and (c) $\mathrm{H}_{2} \mathrm{~S}$.

Apart from $\mathrm{AD}$ temperature, the $\mathrm{CH}_{4}$ concentration in biogas also depends on the $\mathrm{pH}$, as it affects the speciation of the carbonate system and the release of $\mathrm{CO}_{2}$ [7]. The biogas composition shifts more toward $\mathrm{CH}_{4}$ when the $\mathrm{pH}$ is high due to increased alkalinity caused by $\mathrm{NH}_{3}$ release. In this study, the $\mathrm{pH}$ in the autumn was higher and stable than that in the late autumn and winter. Nandi et al. [7] reported a stable and neutral $\mathrm{pH}$ at higher temperatures $\left(30\right.$ and $35{ }^{\circ} \mathrm{C}$ ) than at low temperatures $\left(20\right.$ and $\left.25^{\circ} \mathrm{C}\right)$, which resulted in higher $\mathrm{CH}_{4}$ concentration. From the autumn to winter, the $\mathrm{CH}_{4}$ concentration decreased with a corresponding rise in $\mathrm{CO}_{2}$ concentration due to the drop in $\mathrm{pH}$ (Figure 9b). 
The $\mathrm{H}_{2} \mathrm{~S}$ is considered as an impurity in the biogas composition. Biogas can be used to fuel combustion engines. High amounts of $\mathrm{H}_{2} \mathrm{~S}$ in biogas can be corrosive to the engine and metal parts through the emission of $\mathrm{SO}_{2}$ during combustion, especially when the engine is not operated continuously. Furthermore, combustible products of $\mathrm{H}_{2} \mathrm{~S}$-laden biogas may contain toxic $\mathrm{H}_{2} \mathrm{~S} / \mathrm{SO}_{2}$ gas mixture which is detrimental to human health at the occupational level [35]. Besides the downstream impact, high concentration of $\mathrm{H}_{2} \mathrm{~S}$ can affect the AD process itself, resulting in collapse or even failure of it in worst cases [36]. In the present context, the average $\mathrm{H}_{2} \mathrm{~S}$ concentration in the winter was $4128 \mathrm{ppm}$, which was higher than that of in the autumn (3470 ppm) and late autumn (3379.5 ppm), respectively (Figure 9c). The highest $\mathrm{H}_{2} \mathrm{~S}$ concentration was measured as 4499 ppm on February 10, which represents the middle of winter. Jung et al. [37] also observed high $\mathrm{H}_{2} \mathrm{~S}$ concentration at low ambient temperature. It was interesting to see that the $\mathrm{H}_{2} \mathrm{~S}$ concentration obtained in this experiment was much higher than in the laboratory experiments conducted by Saha et al. [38], who obtained a $\mathrm{H}_{2} \mathrm{~S}$ concentration of $225 \mathrm{ppm}$. The difference was perhaps due to the different mode of operation or operating conditions [39]. The lab-scale study [38] was conducted using batch bottles in a controlled environment. The batch digester was filled with substrates and then sealed till the end of the experiment, whereas the present study was conducted using a fixed-dome digester of continuous mode in an uncontrolled environment. Haghighatafshar [40] observed a high growth rate of sulfate-reducing bacteria in continuous digestion, which resulted in high concentration of $\mathrm{H}_{2} \mathrm{~S}$ in biogas. A high concentration of $\mathrm{H}_{2} \mathrm{~S}$ in the field-scale digester was also observed in a previous study [41], which observed an average $\mathrm{H}_{2} \mathrm{~S}$ concentration of $4310 \mathrm{ppm}$ from an anaerobic digester treating dairy manure. The $\mathrm{H}_{2} \mathrm{~S}$ in biogas comes from inorganic sulfate that presents in the feedstock. The $\mathrm{H}_{2} \mathrm{~S}$ is produced through the action of sulfate-reducing bacteria which compete with methanogens for the intermediate carbon sources [42]. High $\mathrm{H}_{2} \mathrm{~S}$ concentration in the winter season might be due to higher activity of sulfate-reducing bacteria than methanogens causing a high rate of sulfidogenesis [43]. Thus, it can be concluded that the low temperature is responsible for higher $\mathrm{H}_{2} \mathrm{~S}$ concentration during the winter season. The presence of $\mathrm{H}_{2} \mathrm{~S}$ hinders the production of methane [44], making biogas unsuitable for downstream application. As for example, the recommended concentration of $\mathrm{H}_{2} \mathrm{~S}$ in biogas is $<10 \mathrm{ppm}$ for kitchen stoves, $<500 \mathrm{ppm}$ for combustion engines, and $<1000 \mathrm{ppm}$ for boilers, respectively [45], suggesting that the filtering of biogas is necessary before feeding to an engine or to other biogas-run applications.

\subsection{Electricity Production}

Figure 10 shows the average daily electricity production from the produced biogas in different seasons. The results show that electricity production in the winter $(182.5 \mathrm{kWh})$ was $47.85 \%$ and $45.15 \%$ lower than in the autumn $(350 \mathrm{kWh})$ and late autumn $(332.72 \mathrm{kWh})$, respectively. However, electricity production in the late autumn was only $4.94 \%$ lower than in the autumn. With the produced biogas, a generator of $100 \mathrm{~kW}$ could run for 3.5, 3.33, and $1.83 \mathrm{~h}$ in the autumn, late autumn, and winter months, respectively. The reason for less electricity production in the winter can be correlated with the lower digester temperature $\left(25.76^{\circ} \mathrm{C}\right)$, which might have influenced the biogas production and consequently lowered the methane concentration in the biogas by compromising the metabolic activity of methane formers. 


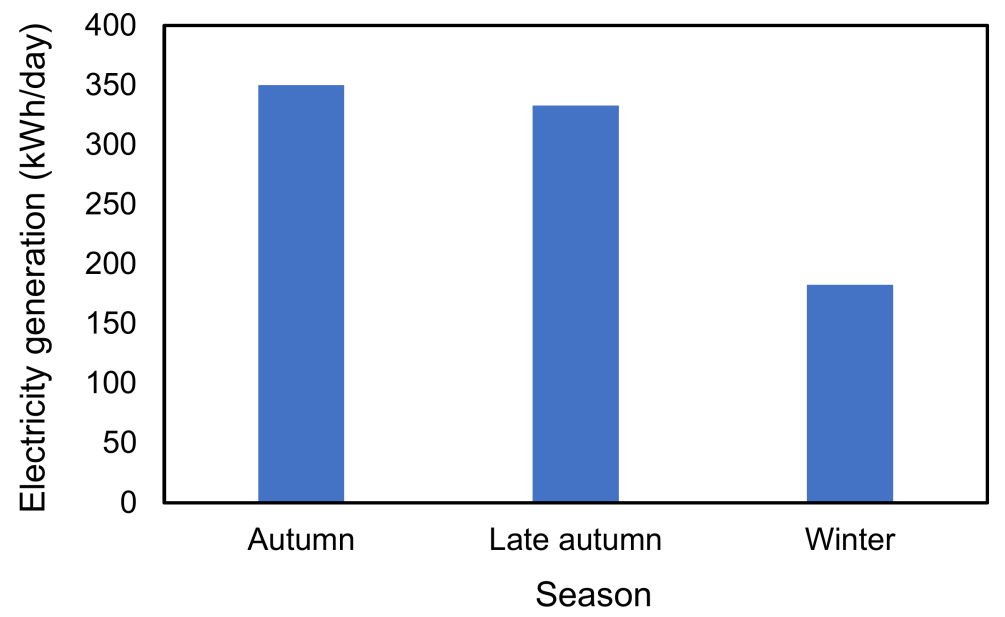

Figure 10. Daily average electricity generation in different seasons.

\subsection{Digester Heating}

Based on the present investigation, it seems that the digester should use a heating unit for temperature control as the digester temperature was found to often deviate to some extent from the optimum AD temperature. Installing such a unit is also likely to improve $\mathrm{AD}$ performance in terms of maximizing biogas yield with minimum $\mathrm{H}_{2} \mathrm{~S}$ production. However, digester heating could result in extra costs for biogas plant operation. A number of previous studies examined the various ways of reducing the cost of digester heating, employing waste heat, solar heating, or surplus heat using heat pumps or heat exchangers [46]. For example, Liu et al. [47] evaluated the performance of a groundwater source heat pump to heat the digester in the winter and found a saving of $44 \%$ standard coal consumption. Gaballah et al. [48] developed a greenhouse-assisted solar heating system, where the greenhouse was made with polyethylene plastic. The study concluded that a digester temperature of around $5{ }^{\circ} \mathrm{C}$ higher than the ambient temperature can be reached using the proposed system. Dong and Lu [49] proposed a solar heating system, in which water is heated first by a solar collector, and then directly added to the digester. The system showed $11.3 \%$ improvement in the biogas yield over the unheated digester. Axaopoulos [50] proposed a solar heating system for an underground digester. The digester was constructed with flat plate solar collectors with an area of $32 \mathrm{~m}^{2}$. The results showed that by using the heating system, the digester temperature could be maintained at about $33.5^{\circ} \mathrm{C}$. However, a combined heat and power generation (CHP) system would be most appropriate for a commercial-scale plant as they intend to produce both heat and electricity. The waste heat from the combustion of biogas can be utilized to heat the digester content by using heating pipes (internal heating) or to preheat the substrate prior to feeding into the digester using a heat exchanger (external heating) [51]. Lantz [52] found a drastic reduction in the cost of biogas production using a CHP system with a compression ignition engine, where heat exchangers were used to heat the substrate to maintain the optimum digester temperature.

In line with the above studies, design and installation of a digester heating unit suitable with regard to both $\mathrm{AD}$ performance and cost remains to be a scope of the future research based on the current work.

\section{Conclusions}

The operational temperature and performance of a fixed-dome type digester at local conditions were monitored. The result showed that during a specific season the slurry temperature remained nearly constant, but in the long run the slurry temperature decreased from autumn to winter due to the drop in ambient temperature. The biogas composition varied seasonally as a result of temperature variations from season to season. Higher methane and lower $\mathrm{CO}_{2}$ concentrations were observed in the autumn than in the late au- 
tumn and winter. The $\mathrm{H}_{2} \mathrm{~S}$ concentration was higher during the winter than in the autumn and late autumn seasons. The electricity generation from produced biogas was much lower in the winter than in the autumn and late autumn. Since the drop in temperature from the autumn to winter resulted in reduced methane concentration and higher $\mathrm{H}_{2} \mathrm{~S}$ production, it is recommended to use a heating control unit in the winter season to avoid instability in biogas production. Additionally, before using the biogas to generate electricity via combustion, the $\mathrm{H}_{2} \mathrm{~S}$ cleaning unit prior to biogas feeding to the system should be added.

As the experiment was conducted for six months, further study could be carried out considering all year-round temperature variations. In addition, an economic analysis of the digester with a heating unit can be performed to understand the economic viability of the system.

Author Contributions: Conceptualization, A.S.M.Y.B.S., M.F.U.Z. and C.K.S.; methodology A.S.M.Y.B.S., M.F.U.Z., R.N. and C.K.S.; formal analysis, A.S.M.Y.B.S., R.N. and S.S.; investigation, A.S.M.Y.B.S. and M.F.U.Z.; resources, C.K.S. and M.M.A.; data curation, A.S.M.Y.B.S. and R.N; writing-original draft preparation, A.S.M.Y.B.S., M.F.U.Z. and R.N.; writing-review and editing, R.N., C.K.S., M.M.A. and S.S.; visualization, A.S.M.Y.B.S. and R.N.; supervision, C.K.S. and M.M.A.; project administration, C.K.S. and M.M.A.; funding acquisition, M.M.A. and S.S. All authors have read and agreed to the published version of the manuscript.

Funding: This work was funded by the International Finance Corporation (IFC), Bangladesh (grant number 600237) and the APC was funded by the Norwegian University of Science and Technology (NTNU).

Data Availability Statement: Data can be provided upon request.

Acknowledgments: We express our gratitude towards Phenix Pvt. Ltd. (Samiul Agro Complex Ltd.), Gazipur for allowing us to conduct the experiments.

Conflicts of Interest: The authors declare no conflict of interest.

\section{References}

1. Bangladesh Bureau of Statistics (BBS). Bangladesh Statistics. Available online: http://bbs.portal.gov.bd/sites/default/files/files/ bbs.portal.gov.bd/page/a1d32f13_8553_44f1_92e6_8ff80a4ff82e/Bangladesh\%20\%20Statistics-2018.pdf (accessed on 10 October 2018).

2. Bangladesh Power Development Board (BPDB). Annual Report 2018-2019. Available online: https://www.bpdb.gov.bd/bpdb_ new/resourcefile/annualreports/annualreport_1574325376_Annual_Report_2018-19.pdf (accessed on 10 October 2019).

3. International Energy Agency (IEA). World Energy Statistics Report 2018. Available online: https://www.iea.org/ (accessed on 5 April 2021).

4. Bangladesh Power Development Board. BPDB Key Statistics. 2021. Available online: https://bd.bpdb.gov.bd/bpdb_new/index. php/site/page/13e9-2cc0-ce41-9c09-088d-94d5-f546-04a6-b4fa-1d18. (accessed on 10 October 2020).

5. Shetol, H.; Rahman, M.M.; Sarder, R.; Hossain, M.I.; Riday, F.R. Present status of Bangladesh gas fields and future development: A review. J. Nat. Gas Geosci. 2019, 4, 347-354. [CrossRef]

6. Arikan, O.A.; Mulbry, W.; Lansing, S. Effect of temperature on methane production from field-scale anaerobic digesters treating dairy manure. Waste Manag. 2015, 43, 108-113. [CrossRef]

7. Nandi, R.; Saha, C.K.; Sarker, S.; Huda, M.S.; Alam, M.M. Optimization of reactor temperature for continuous anaerobic digestion of cow manure: Bangladesh perspective. Sustainability 2020, 12, 8772. [CrossRef]

8. Rahman, A.; Møller, H.B.; Saha, C.; Alam, M. The Effect of Temperature on the Anaerobic Co-Digestion of Poultry Droppings and Sugar Mill Press Mud. Biofuels 2019. [CrossRef]

9. Nasir, I.M.; Ghazi, T.I.M.; Omar, R. Anaerobic digestion technology in livestock manure treatment for biogas production: A review. Eng. Life Sci. 2012, 12, 258-269. [CrossRef]

10. Im, S.; Petersen, S.O.; Lee, D.; Kim, D.H. Effects of storage temperature on $\mathrm{CH}_{4}$ emissions from cattle manure and subsequent biogas production potential. Waste Manag. 2020, 101, 35-43. [CrossRef]

11. Schmidt, T.; Harris, P.; Lee, S.; McCabe, B.K. Investigating the impact of seasonal temperature variation on biogas production from covered anaerobic lagoons treating slaughterhouse wastewater using lab scale studies. J. Environ. Chem. Eng. 2019, 7, 103077. [CrossRef]

12. Barik, D.; Murugan, S. Assessment of sustainable biogas production from de-oiled seed cake of karanja-an organic industrial waste from biodiesel industries. Fuel 2015, 148, 25-31. [CrossRef]

13. Rahman, A.; Saha, C.; Ward, A.J.; Møller, H.B.; Alam, M. Anaerobic Co-Digestions of Agro-Industrial Waste Blends Using Mixture Design. Biomass Bioenergy 2019, 122, 156-164. [CrossRef] 
14. Rahman, A.; Møller, H.B.; Alam, M. Assessing the Energy Potential of Agricultural Residues and an Approach to Meet the Rural Energy Demand: The Bangladesh Perspective. Biomass Convers. Biorefin. 2018, 8, 925-934. [CrossRef]

15. Talukder, M.F.S.I. Impact Assessment of Biogas Plants: A Case Study in Bangladesh. Master's Thesis, Energy and Environmental Management, International Institute of Management, University of Flensburg, Flensburg, Germany, 2010.

16. GEKH. Survey Report on Biogas Plants in Bangladesh by Green Energy Knowledge Hub; Bangladesh Agricultural University: Mymensingh, Bangladesh, 2016.

17. Nandi, R.; Saha, C.K.; Huda, M.S.; Alam, M.M. Effect of Mixing on Biogas Production from Cowdung. Eco Friendly Agric. J. 2017, 10,7-13.

18. Islam, A.R.M.T.; Shen, S.; Hu, Z.; Rahman, M.A. Drought Hazard Evaluation in Boro Paddy Cultivated Areas of Western Bangladesh at Current and Future Climate Change Conditions. Adv. Meteorol. 2017, 2017, 3514381. [CrossRef]

19. Khatun, M.A.; Rashid, M.B.; Hygen, H.O. Climate of Bangladesh. MET Report. Available online: https://www. met.no/publikasjoner/met-report/met-report-2016/_/attachment/download/b50e3f06-4485-4f34-b642-0a1e86f12c7d: a483b63367b0f087f3bd9410e135a5e0837d1927/MET-report-08-2016.pdf (accessed on 31 May 2016).

20. Bangladesh Climate Data Portal. Available online: http://bmd.wowspace.org/team/homex.php (accessed on 5 April 2021).

21. Hubert, C.; Steiniger, B.; Schaum, C.; Michel, M.; Spallek, M. Variation of the Digester Temperature in the Annual Cycle-Using the Digester As Heat Storage. Water Pract. Technol. 2019, 14, 471-481. [CrossRef]

22. Kalia, A.; Kanwar, S. Long-Term Evaluation of a Fixed Dome Janata Biogas Plant in Hilly Conditions. Bioresour. Technol. 1998, 65, 61-63. [CrossRef]

23. Ihara, I.; Yano, K.; Andriamanohiarisoamanana, F.J.; Yoshida, G.; Yuge, T.; Yuge, T.; Tangtaweewipat, S.; Umetsu, K. Field Testing of a Small-Scale Anaerobic Digester With Liquid Dairy Manure and Other Organic Wastes at an Urban Dairy Farm. J. Mater. Cycles Waste Manag. 2020, 22, 1382-1389. [CrossRef]

24. Castano, J.M.; Martin, J.F.; Ciotola, R. Performance of a small-scale, variable temperature fixed dome digester in a temperate climate. Energies 2014, 7, 5701-5716. [CrossRef]

25. Terradas-Ill, G.; Pham, C.H.; Triolo, J.M.P.; Martí-Herrero, J.; Sommer, S.G. Thermic Model to Predict Biogas Production in Unheated Fixed-Dome Digesters Buried in the Ground. Environ. Sci. Technol. 2014, 48, 3253-3262. [CrossRef] [PubMed]

26. APHA. Standard Methods for the Examination of Waste Water, 23rd ed.; American Public Health Association: Washington, DC, USA, 2017.

27. Nasrin, T.; Saha, C.K.; Nandi, R.; Huda, M.S.; Alam, M.M. Kinetic study and optimization of total solids for anaerobic digestion of kitchen waste: Bangladesh perspective. Water Sci. Technol. 2021, 84, 1136-1145. [CrossRef]

28. Zinder, S.H. Physiological Ecology of Methanogens. In Methanogenesis. Chapman E Hall Microbiology Series (Physiology/Ecology/Molecular Biology/Biotechnology); Ferry, J.G., Ed.; Springer: Boston, MA, USA, 1993. [CrossRef]

29. Sarker, S.; Lamb, J.J.; Hjelme, D.R.; Lien, K.M. A Review of the Role of Critical Parameters in the Design and Operation of Biogas Production Plants. Appl. Sci. 2019, 9, 1915. [CrossRef]

30. Kalia, A.K.; Kanwar, S.S. Temperature Profiles of Biogas Plants Operating under Hilly Conditions. Biol. Wastes 1989, 30, 217-224. [CrossRef]

31. Wang, S.; Ma, F.; Ma, W.; Wang, P.; Zhao, G.; Lu, X. Influence of temperature on biogas production efficiency and microbial community in a two-phase anaerobic digestion system. Water 2019, 11, 133. [CrossRef]

32. Guo, P.; Zhou, J.; Ma, R.; Yu, N.; Yuan, Y. Biogas production and heat transfer performance of a multiphase flow digester. Energies 2019, 12, 1960. [CrossRef]

33. Browne, J.D.; Gilkinson, S.R.; Frost, J.P. The Effects of Storage Time and Temperature on Biogas Production from Dairy Cow Slurry. Biosyst. Eng. 2015, 129, 48-56. [CrossRef]

34. Vanegas, C.; Bartlett, J. Anaerobic Digestion of Laminaria Digitata: The Effect of Temperature on Biogas Production and Composition. Waste Biomass Valorization 2012, 4, 509-515. [CrossRef]

35. Choudhury, A.; Shelford, T.; Felton, G.; Gooch, C.; Lansing, S. Evaluation of Hydrogen Sulfide Scrubbing Systems for Anaerobic Digesters on Two U.S. Dairy Farms. Energies 2019, 12, 4605. [CrossRef]

36. Zulkefli, N.N.; Masdar, M.S.; Jahim, J.; Harianto, E. Overview of $\mathrm{H}_{2} \mathrm{~S}$ removal technologies from biogas production. Int. J. Appl. Eng. Res. 2016, 11, 10060-10066.

37. Jung, H.; Kim, J.; Lee, C. Temperature effects on methanogenesis and sulfidogenesis during anaerobic digestion of sulfur-rich macroalgal biomass in sequencing batch reactors. Microorganisms 2019, 7, 682. [CrossRef]

38. Saha, C.K.; Rahman, M.; Moller, H.B.; Alam, M.M. Biogas production from animal manure and poultry litter in Bangladesh. In Proceedings of the 4th CIGR - International Conference of Agricultural Engineering (CIGR-AgEng2016): Automation, Environment and Food Safety, Aarhus, Denmark, 26-29 June 2016.

39. Guo, J.; Dong, R.; Clemens, J.; Wang, W. Performance Evaluation of a Completely Stirred Anaerobic Reactor Treating Pig Manure at a Low Range of Mesophilic Conditions. Waste Manag. 2013, 33, 2219-2224. [CrossRef]

40. Haghighatafshar, S.; Kjerstadius, H.; Jansen, J.L.C.; Davidsson, Å. Management of hydrogen sulfide in anaerobic digestion of enzyme pretreated marine macro-algae. Vatten-J. Water Manag. Res. 2012, 68, 265-273.

41. Lansing, S.A.; Klavon, K.H.; Mulbry, W.W.; Moss, A.R. Design and validation of field-scale anaerobic digesters treating dairy manure for small farms. Trans. Asabe 2015, 58, 441-449. [CrossRef] 
42. Spyridonidis, A.; Vasiliadou, I.A.; Akratos, C.S.; Stamatelatou, K. Performance of a full-scale biogas plant operation in greece and its impact on the circular economy. Water 2020, 12, 3074. [CrossRef]

43. Shende, A.D.; Pophali, G.R. Anaerobic Treatment of Slaughterhouse Wastewater: A Review. Environ. Sci. Pollut. Res. 2021, 28, 35-55. [CrossRef]

44. Kavuma, C. Variation of Methane and Carbon Dioxide Yield in a Biogas Plant. Master's Thesis, Royal Institute of Technology, Stockholm, Sweden, 2013.

45. Knight, L.; Presnell, S. Death by sewer gas: Case report of a double fatality and review of the literature. Am. J. Forensic. Med. Pathol. 2005, 26, 181-185. [CrossRef] [PubMed]

46. Zhang, T.; Tan, Y.; Zhang, X. Using a Hybrid Heating System to Increase the Biogas Production of Household Digesters in Cold Areas of China: An Experimental Study. Appl. Therm. Eng. 2016, 103, 1299-1311. [CrossRef]

47. Liu, J.; Li, W.Z.; Chen, S.W. Heating mode of biogas plant in alpine region based on underground water source heat pump. Trans. Chin. Soc. Agric. Eng. 2013, 29, 163-169.

48. Gaballah, E.S.; Abdelkader, T.K.; Luo, S.; Yuan, Q.; Abomohra, A.E.F. Enhancement of biogas production by integrated solar heating system: A pilot study using tubular digester. Energy 2020, 193, 116758. [CrossRef]

49. Dong, F.; Lu, J. Using Solar Energy to Enhance Biogas Production from Livestock Residue - A Case Study of the Tongren Biogas Engineering Pig Farm in South China. Energy 2013, 57, 759-765. [CrossRef]

50. Axaopoulos, P.; Panagakis, P.; Tsavdaris, A.; Georgakakis, D. Simulation and Experimental Performance of a Solar-Heated Anaerobic Digester. Sol. Energy 2001, 70, 155-164. [CrossRef]

51. Han, R.; Hagos, K.; Ji, X.; Zhang, S.; Chen, J.; Yang, Z.; Lu, X.; Wang, C. Review on Heat-Utilization Processes and Heat-Exchange Equipment in Biogas Engineering. J. Renew. Sustain. Energy 2016, 8, 032701. [CrossRef]

52. Lantz, M. The Economic Performance of Combined Heat and Power from Biogas Produced from Manure in Sweden - A Comparison of Different CHP Technologies. Appl. Energy 2012, 98, 502-511. [CrossRef] 